\title{
PHYTOPLANKTON PHOTOSYNTHESIS-LIGHT RELATIONSHIP IN THE PAS ESTUARY, CANTABRIA, SPAIN
}

\author{
Luisa Pérez and J.C. Canteras. \\ Laboratory of Ecology. Dpto. Ciencias y Técnicas del Agua y Medio Ambiente. University of Cantabria. 39005-Santander. Spain.
}

Key words: light, photosynthetic parameters, nutrients, estuary, Spain.

\begin{abstract}
The relationship between the photosynthesis-irradiance (P-I) curves of natural phytoplankton assemblages and environmental conditions was investigated in a partially mixed estuary, the Pas. During an annual cycle, photosynthesis was measured both by in situ and laboratory (light-saturation curve) incubation methods.

The initial slope $\left(\mathrm{a}^{\mathrm{B}}\right)$ and the maximum photosynthetic rate $\left(\mathrm{P}^{\mathrm{B}} \max \right)$ of $\mathrm{P}-\mathrm{I}$ curves changed significantly over the year. The parameter $\left(\alpha^{B}\right)$ ranged from 0.001 to $0.04 \mathrm{mgC}(\mathrm{mgChl} a)^{1} \mathrm{~h}^{-}\left(\mu \mathrm{E} \mathrm{m} \mathrm{m}^{-2} \mathrm{~s}^{1}\right)$ and $\mathrm{P}^{\mathrm{B}}{ }_{\max }$ ranged from 0.6 to $15 \mathrm{mgC}(\mathrm{mgChl} a)^{-1} \mathrm{~h}^{\prime}$. Maxima for both $\alpha^{\mathrm{B}}$ and $\mathrm{P}^{\mathrm{B}}$ max occurred when the community of phytoplankton was dominated by small cell (small diatoms, Cryptornonas sp.) and the minima were obtained when the extinction coefficient was highest. In field (in situ) incubations, the production normalized to chlorophyll a $\left(\mathrm{P}^{\mathrm{D}} \mathrm{i}\right)$ correlated positively with salinity and negatively with the nutrient concentration.
\end{abstract}

\section{INTRODUCTION}

Primary production is regulated spatially and temporally by chemical, physical, and biological factors. The study of this regulation is difficult and particullarly so in estuarine ecosystems where conditions change rapidly and within a wide range.

The parameters of the photosynthesis-irradiance (P-I) curves $\left(\mathrm{a}^{\mathrm{B}}=\right.$ initial slope, $\mathrm{P}^{\mathrm{B}} \max =$ maximum photosynthetic rate $)$ and their relationship to environmental factors have been studied to achieve a better understanding of the control of photosynthesis in natural phytoplankton assemblages (COTE and PLATT, 1983). These parameters provide more physiological information than what is available from water column profiles (PLATT and JASSBY, 1976). HARRISON et al., (1985) suggested that P-I parameters chosen from a single depth stratum (upper mixed-layer) may be adequate in most cases to estimate total column production even under conditions of vertical stratification.

$\mathrm{P}_{\text {max }}$ is perhaps the easiest photosyntheic parameter to use to compare measurements between the laboratory and the field, because it is relatively insensitive to differences in light quality, its calculation does not rely on accurate measurement of irradiance, and it can reasonably be compared to the maximum $\mathrm{P}^{\mathrm{B}}$ measured in vertical profiles (CULLEN, 1991). The inital slope a, is the product of the specific absorption coefficient for chlorophyl $a$, and the quantum yield for photosynthesis $\emptyset_{\max }$. It is a measure of photosynthetic efficiency, but it is not equivalent to quantum yield. The magnitude is sensitive to the spectral quality of the light source and the absorption characteristics of the phytoplankton (CULLEN, 1991).

In this work we present the results obtained from the measurement of the assimilation number, $\mathrm{P}^{\mathrm{B}_{\mathrm{i}}}$ in situ, and the calculation of P-I parameter as well as their relationship to environmental factors in a small estuary.

\section{STUDY AREA}

The Pas Estuary (N. Spain) (Fig. 1) is an estuary which is typical for a flooded-valley. The depth increases towards the mouth, and average depth is $4 \mathrm{~m}$. The average width as far as Mogro (Fig. 1) is 50-60 m. Beyond this area, the width of the river averages 50-60 m during low tide, and increases up to 200 $\mathrm{m}$ during medium tide.

The tides are semidiurnal with a fortnightly alternating cycle of spring and neap tides. The interval between two consecutive 


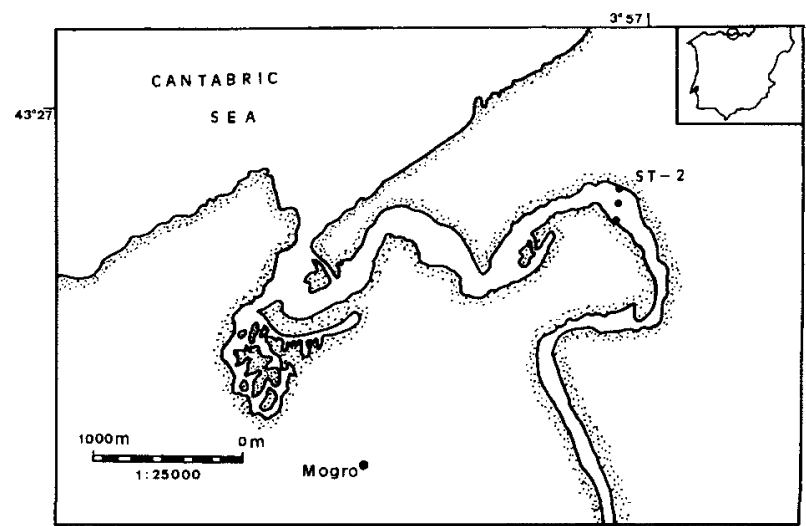

FIGURE 1. Map of the Pas estuary (N. Spain) showing the location of the station studied (Station 2).

FIGURA 1. Mapa del estuario del rio Pas (N. España), mostrando la localización de la estación estudiada.

tides corresponds to the semilunar wave $\mathrm{M}$, (12 h $25 \mathrm{~min}$ ). The tidal amplitude is about $4 \mathrm{~m}$ in spring tides and approximately $2 \mathrm{~m}$ for neap tides. The maximum volume of the salt water wedge is $4,550,000 \mathrm{~m}^{3}$.

\section{METHODS}

Samples were collected over an annual cycle at Station 2 (Fig. 1) using $8 \mathrm{I}$ Van Dorn bottles. Determination of $\mathrm{P}^{\mathrm{B}_{i}}$ was done in situ while P-I experiments were conducted in the laboratory.

For the measurement of photosynthetic rate, 5 samples were collected (Fig. 2). The ${ }^{14} \mathrm{C}$ method (STEEMAN-NIELSEN, 1952) was used to measure the photosynthesis. Transparent and opaque bottles $(250 \mathrm{ml})$, inoculated with $5 \mu \mathrm{Ci}$ of $\mathrm{NaH}^{14} \mathrm{CO}$. were incubated in situ for two hours. Following incubation, samples were filtered ( $0.45 \mathrm{pm}$ poro size, $25 \mathrm{~mm}$ diameter), and placed in liquid scintillation counting vials. Each filter was fumed over $\mathrm{HCl}$ and $10 \mathrm{ml}$ of scintillation cocktail was added. All samples were counted on a Liquid Scintillation Counter. The photosynthesis was estimated by the VOLLENWEIDER method (1969). Sampling alternated between high and low tide to examine tidal effects on photosynthesis.

For the P-I experiment, the water was taken at the surface, $\mathrm{S}$ (Fig. 2) during high tide. Samples were carried to the laboratory in a portable refrigerator. The time between the sampling and the incubation was half an hour. In the laboratory $5 \mu \mathrm{Ci}$ of $\mathrm{NaH}^{14} \mathrm{CO}_{3}$ was added to each bottle $(250 \mathrm{ml})$. The bottles were incubated at $18{ }^{\circ} \mathrm{C}$, in a room with a temperature control system, for $4 \mathrm{~h}$ over a range of light intensity. The irradiance ranged from 0 to the estuary light intensity when the sampling was carried out (maximum values $1600 \mu \mathrm{E} \mathrm{m}^{-2} \mathrm{~s}^{1}$ ).
All photosynthesis values were normalized to the chlorophyll "a" concentration. The light-limited and saturated parameters of the P-I curves $\left(\alpha^{\mathrm{B}}=\operatorname{mgC}\left(\mathrm{mg}\right.\right.$ Chla) ' $h^{\mathbf{l}}\left(\mu \mathrm{Em}^{2} \mathrm{~s}^{1}\right)$ and $\left.\mathrm{P}^{\mathrm{B}} \max =\operatorname{mgC}(\operatorname{mgChl} a)^{1} \mathbf{h}^{1}\right)$ were estimated according to PLATT et al., 1980.

All water samples were analyzed for salinity, temperature, nutrients (nitrate, nitrite, ammonium, soluble reactive phosphate (SRP) and silicate), chlorophyll a, and total number of cells. Methods described in STRICKLAND and PARSONS (1972) were used. Phytoplankton counts were done with an inverted microscope (UTERMOHL, 1958), and depending on the density of cells, 25 or $50 \mathrm{ml}$ sedimentation chambers were used.

Incident $\left(\mathrm{I}_{0}\right)$ and subsurface $\left(\mathrm{I}_{z}\right)$ light intensity were measured in situ (Licor 850) and the diffuse attenuation coefficient $\left(\mathrm{k}: \mathrm{m}^{1}\right)$ calculated as follows: $\mathrm{k}=\left(\ln \mathrm{I}_{0}-\ln \mathrm{I}_{z}\right) / \mathrm{z}$.

The statistical significance of differences in averages was obtained by means of an analysis of variance. This analysis was designed considering the three variation factors. Factor A: state of tides (low tide and high tide); Factor B: points where samples were taken (at the water column: surface (S); midway (M); and bottom (B); and the littoral right (LA) and littoral left

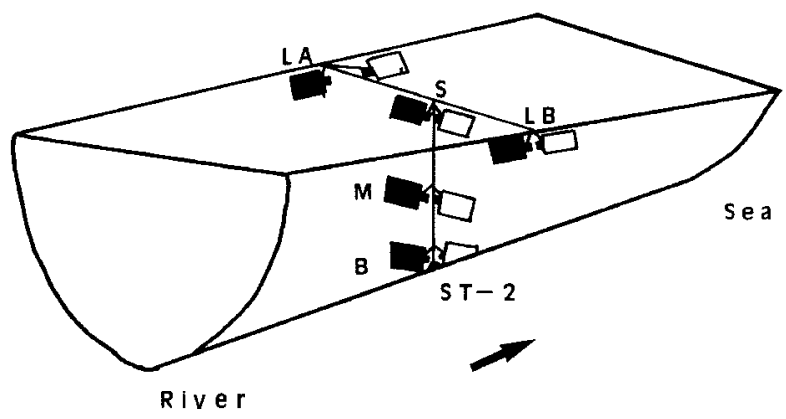

FIGURE 2. Station and sampling points $(\mathrm{S}=$ surface of central point, $\mathrm{M}=$ midwway of central point, $\mathrm{B}=$ bottom of central point, $\mathrm{LA}=$ littoral right, $\mathrm{LB}=$ littoral left). Arrangement of the transparent and opaque bottles during incubation for measurement of the photosynthesis.

FIGURA 2. Estación y puntos de muestreo ( $\mathrm{S}=$ superficie del punto central, $\mathrm{M}=$ punto medio, $\mathrm{B}=$ fondo del punto central, $\mathrm{LA}=$ litoral derecho, $\mathrm{LB}=$ litoral izquierdo). Disposición de las botellas trasparentes y opacas durante la incubación para la medida de la fotosintesis in situ.

(LB) (Fig. 2); Factor C: annual cycle. The analysis was performed using the SPSS program in a personal computer.

\section{RESULTS and DISCUSSION}

The annual cycle of hydrographical characteristics exhibits a period of high temperature and salinity in summer and early autumn, and low salinity in winter and during periods with 

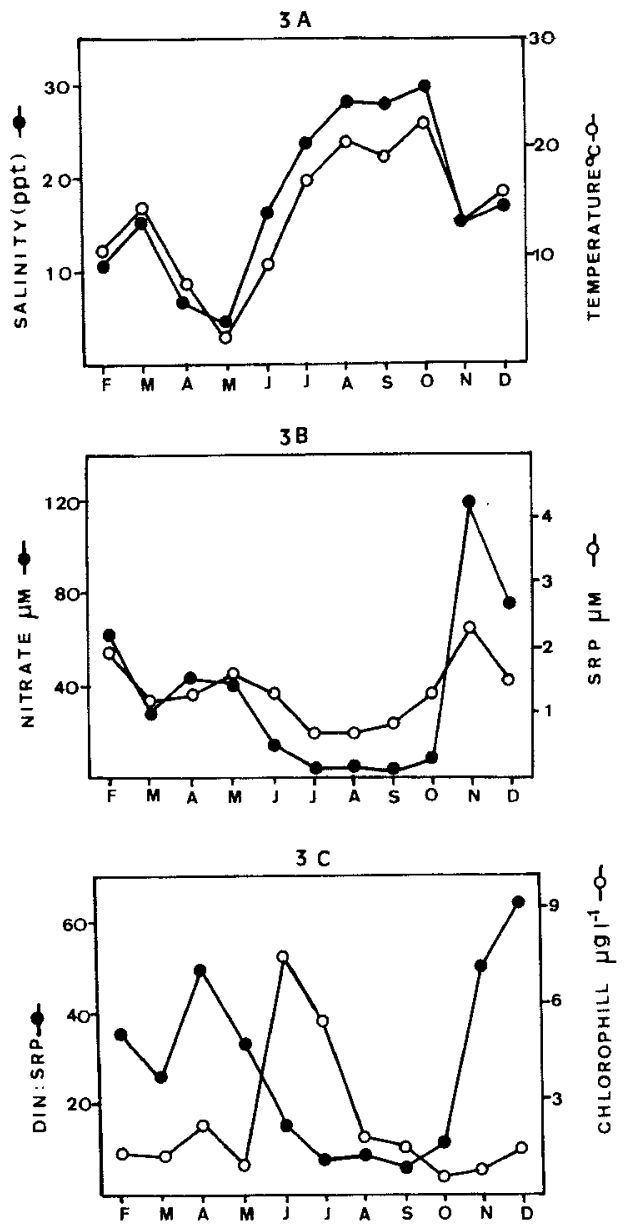

FIGURE 3. Seasonal variations of mean values $(n=10)$ of physical, chemical and biological characteristics at the Station 2: a. Salinity (ppt) and Temperature $\left({ }^{\circ} \mathrm{C}\right)$. b. Nitrate $(\mu \mathrm{M})$ and SRP $(\mu \mathrm{M})$. c. DIN: SRP ratios and Chlorophyll $a\left(\mu \mathrm{g} \mathrm{1}^{-1}\right)$. FIGURA 3. Variación estacional de los valores medios $(\mathrm{n}=10)$ de las características físicas, químicas y biológicas en la Estación 2: a. Salinidad (ppt) y Temperatura $\left({ }^{\circ} \mathrm{C}\right)$ b. nitrato $(\mu \mathrm{M})$ y fósforo reactivo soluble $(\mu \mathrm{M})$. c. Relación Nitrógeno inorgánico disuelto: fósforo reactivo soluble y clorofila $a\left(\mu \mathrm{gl}^{-1}\right.$.

high precipitation (April and May) (Fig. 3A). The pattern of nutrient concentrations (Fig. 3B) was as follows: continuous vertical stratification; maxima in winter and seasons with frequent rain and minima during summer; nutrient concentrations were lower at high tide than at low tide. Hydrographical characteristics and nutrients cycle have been described in a previous paper (PÉREZ and CANTERAS, 1990). The chlorophyll $a$ concentrations (Fig. 3C) ranged from 8 to $0.5 \mu / \mathrm{L}$ with the lowest values in winter and at the end of spring. A small increase occurred in March, although maximum biomass was recorded in June.

With respect to abundance and specific composition of phytoplankton, three periods could be distingished in the annual
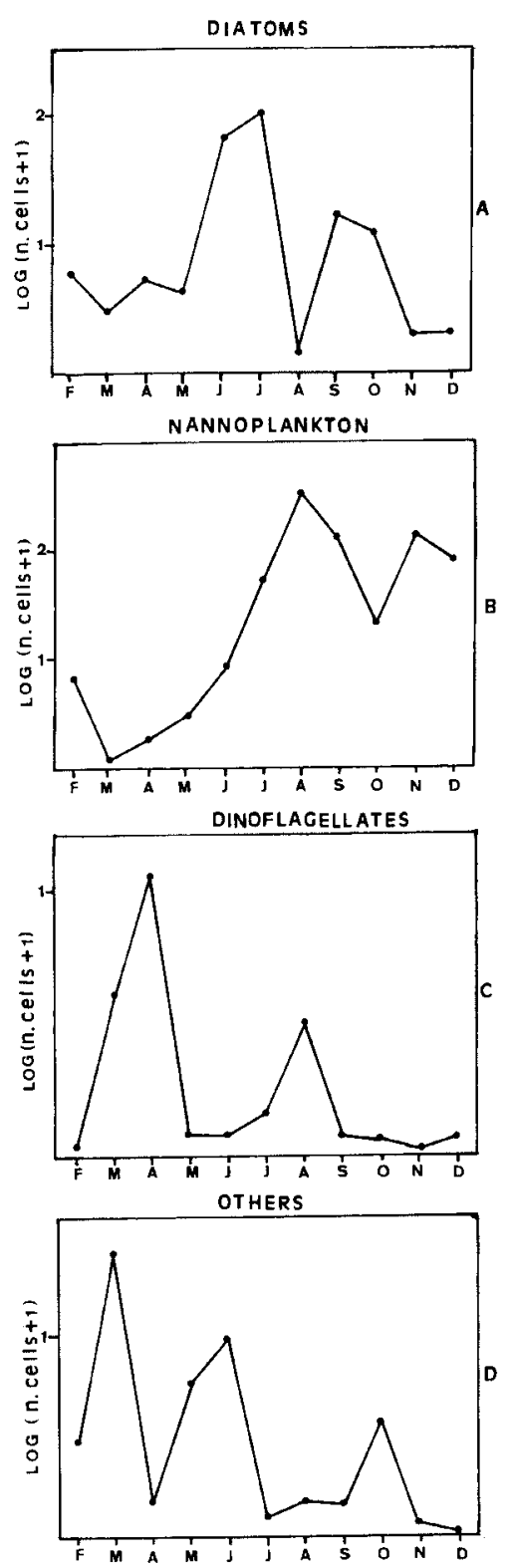

FIGURE 4. Seasonal variations in the cell abundance $(\log x+1), x=$ cells $/ m l)$ in the surface central point (S) at high tide. The group others included Cryptophyceae, Euglenophyceae, Crysophyceae.

FIGURA 4. Variación estacional de la abundancia celular ) $\log \mathrm{x}+1, \mathrm{x}=$ cells $/ \mathrm{ml}$ ) en la superficie del punto central ( $S$ ) en pleamar. El grupo otros incluye Cryptophyceae, Euglenophyceae, Crysophyceae.

cycle: The first period, in which the number of cells was small, averaging 100 cells $\mathrm{ml}^{-1}$ and during which there was a little phytoplankton bloom in March. During the second period, from June to October, there was a rise in the biomass, which reached its maximum in July. The third period, from October to December, showed a reduction in the biomass. Over the annual 
cycle, the phytoplankton was predominantly composed of diatoms (Fig. 4A). Dinoflagellates appeared during August and April (Fig. 4C). Cryptophyceae were present almost all year round, with the largest numbers during June (Mean $=45 \%$ ) and March ( $\mathrm{M}=37 \%$ ) (Fig. 4D). Nannoplankton appeared during

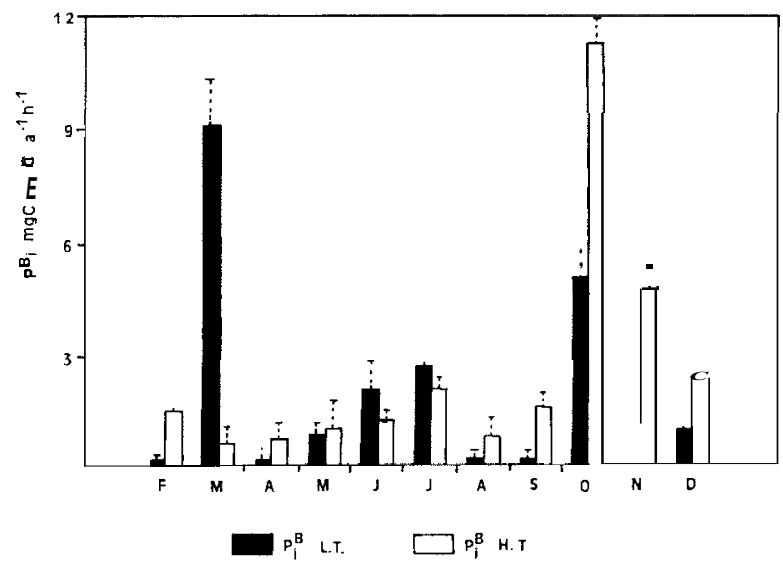

FIGURE 5. Temporal variations $(n=5)$ in assimilation numbers for the $m$ sttu experiment, $\left.\mathrm{P}^{\mathrm{B}} \mathrm{i}(\mathrm{mgC}(\mathrm{mgChl} a))^{\prime} \mathrm{h}^{\prime}\right)$, at high (H.T) and low (L.T.) tide.

FIGURA 5. Variaciones temporales $(n=5)$ del número de asimilación en los experimentos realizados in situ, $\mathrm{P}^{\mathrm{B}} \mathrm{i}\left(\mathrm{mgC}(\mathrm{mgChl} a)^{\prime} \mathrm{h}^{\prime}\right)$, en pleamar (H.T.) y bajamar (L.T.)

the entire annual cycle and accounted for $>50 \%$ of the cell number in the summer months and in the early autumn (Fig. 4B).

Highest assimilation numbers $\left(\mathrm{P}_{1}{ }_{1}\right)$ (Fig. 5) were recorded in March $\left(\right.$ Mean $\left.=9.09 \mathrm{mgC}\left(\mathrm{mgChl}^{\prime}\right)^{1} \mathrm{~h}^{-1}\right)$, Standard Deviation $($ S.D. $)=5.44)$ and October $\left(\mathrm{M}=11.21 \mathrm{mgC}(\mathrm{mgChla})^{t} h^{-1}\right.$, S.D. $=1.89)$. During the rest of the year they were $<5 \mathrm{mgC}(\mathrm{mg} \mathrm{Chl}$ $a)^{1} \mathrm{~h}^{\prime}$. The results of variance analysis are shown in Table I. Only the annual cycle indicated statisticaly significant difference $(\mathrm{p}<0.01)$ among different months.

Table I1 shows the correlation coefficients obtained with salinity $(\mathrm{r}=0.32, \mathrm{p}<0.00 \mathrm{l})$, nutrients (silicate and nitrate) and dissolved oxygen. These correlations have been reported by

TABLE I. Results of variance analyses.

TABLA I. Resultados del análisis de la varianza.

\begin{tabular}{|c|c|c|c|c|c|c|}
\hline Source of variation & D.F. & $\begin{array}{l}\text { Sum of } \\
\text { squares }\end{array}$ & $\begin{array}{l}\text { Mean } \\
\text { squares }\end{array}$ & $\mathrm{F}$ & Po.05 & $P 0.01$ \\
\hline State tidal (A) & I & 0.845 & 0.845 & 0.113 & 251 & 6282 \\
\hline Points of sampling(B) & 4 & 17.089 & 4.272 & 0.574 & 5.71 & 13.74 \\
\hline Annual cycle (C) & 10 & 14603 & 1460.03 & 19.62 & 2.67 & 4.17 \\
\hline Interactions (AB) & 4 & 26.409 & 6.662 & 0.887 & 5.71 & 13.74 \\
\hline Interactions (AC) & 10 & 287.864 & 28.786 & 3.867 & 2.67 & 4.17 \\
\hline Interactions (BC) & 40 & 276.324 & 6.908 & 0.928 & 1.69 & 2.11 \\
\hline Interactions ( $\mathrm{ABC}$ ) & 40 & 297.731 & 7.443 & & & \\
\hline
\end{tabular}

D.F. Degrees of freedom
TABLE II. Significant correlation coefficients obtained between $\mathrm{P}^{\mathrm{B}} \mathrm{i}$ and environmental parameters $($ d. $\mathrm{f} .=108)$

TABLA II. Coeficientes de correlación significativos obtenidos entre $\mathrm{P}^{\mathrm{B}_{\mathrm{i}}}$ y parámetros ambientales $(\mathrm{g} .1 .=108)$.

\begin{tabular}{lllll}
\hline & $\begin{array}{l}\text { Oxigen } \\
\mathrm{mg} / 1\end{array}$ & $\begin{array}{l}\text { Salinity } \\
\mathrm{ppt}\end{array}$ & $\begin{array}{l}\text { Nitrate } \\
\mu \mathrm{M}\end{array}$ & $\begin{array}{l}\text { Silicate } \\
\mu \mathrm{M}\end{array}$ \\
\hline $\mathrm{p}^{\mathrm{B}_{\mathrm{i}}}$ & $-0.21^{*}$ & $0.32 * * *$ & $-0.20^{*}$ & $-0.31^{* * * *}$ \\
${ }^{*} \mathrm{p}<0.05$ & & & & \\
${ }^{* *} \mathrm{p}<0.01$ & & & & \\
${ }^{* * *} \mathrm{p}<0.001$ & & & &
\end{tabular}

other authors (HARRISON and PLATT, 1980) and could indicate a phytoplankton community adapted to neritic conditions, i.e. the community obtains a higher photosynthetic efficiency when salinity is high and nutrient concentrations low. Negative correlation between $\mathrm{P}^{\mathrm{D}} \mathrm{i}$ dissolved oxygen could be due to characteristics of neritic waters which dissolve oxygen in a lesser amount. In the Pas estuary, the contribution of dissolved oxygen to the water is mainly due to physical processes (PÉREZ, 1987). Only occasionaly, biological proccesses increase oxygen concentration.

P-I curves were fitted employing an exponential equation (PLATT et al., 1980). Fig. 6 shows curves obtained from lightgradient incubations, corresponding to samples incubated in January, June and November.

The parameters of the photosynthesis-irradiance curves showed low values in Spring (April $\alpha^{\mathrm{B}}=0.001 \mathrm{mgC}(\mathrm{mgChl} a)$ $\left.\mathrm{h}^{-1}\left(\mu \mathrm{Em}^{2} \mathrm{~s}^{-1}\right) ; \mathrm{P}_{\max }^{\mathrm{B}}=0.5 \mathrm{mgC}(\mathrm{mgChl} a)^{-1} h^{-1}\right)$ and in August $\alpha^{\mathrm{B}}$ $\left.=0.002 \mathrm{mgC}\left(\mathrm{mgChl}^{-1}\right)^{-1} \mathrm{~h}^{-1}\right)\left(\mu \mathrm{Em}^{-2} \mathrm{~s}^{-1}\right) ; \mathrm{P}^{\mathrm{B}} \max =2.6 \mathrm{mgC}-$ $\left.(\mathrm{mgChl} a) \mathrm{h}^{\prime}\right)$. The maxima were obtained in March $\left(\mathrm{a}^{\mathrm{D}}=0.04\right.$ $\left.\mathrm{mgC}(\mathrm{mgChl} a)^{1} \mathrm{~h}^{-1}\left(\mu \mathrm{Em}^{2} \mathrm{~s}^{-1}\right) ; \mathrm{P}^{\mathrm{B}} \max =15 \mathrm{mgC}(\mathrm{mgChl} a)^{-1} \mathrm{~h}^{-1}\right)$ (Fig. 7), when Cryptornonus sp. ( $\operatorname{size}<5 \mu \mathrm{m})$ was predominant $(80 \%)$. The second peak was obtained in October $\left(\alpha^{\mathrm{B}}=0.03 \mathrm{mgC}(\mathrm{mgChl} a)^{-1} \mathrm{~h}^{\prime}\left(\mu \mathrm{Em}^{2} \mathrm{~s}^{-4}\right) ; \mathrm{P}_{\max }^{\mathrm{B}}=13\right.$ $\left.\mathrm{mgC}(\mathrm{mgCh} l a)^{-1} \mathrm{~h}^{-1}\right)$, when the community was dominated by small diatoms, Thalassiosira sp. (diameter $=3 \mathrm{pm}$ ) and Skeletonema costaturn.

The annual average values for $\boldsymbol{a}^{\prime \prime}$ were low during the study $\left(\mathrm{a}^{\mathrm{D}}=0.011 \mathrm{mgC}(\mathrm{mgChl} a){ }^{\prime} \mathrm{h}{ }^{-1}\left(\mu \mathrm{Em}^{-2} \mathrm{~s}^{1}\right)\right.$. The low values of $\alpha^{\mathrm{B}}$ could suggest limitation of photosynthesis. PLATT and JASSBY (1976) gave values of $\alpha^{\mathrm{B}}=0.05 \mathrm{mgC}(\mathrm{mgChl} a)^{\prime} \mathrm{h}$; $\left(\mu \mathrm{Em}^{-2} \mathrm{~s}^{-1}\right)(0.02$ to 0.16$)$ in Nova Scotia; $0.05 \mathrm{mgC}(\mathrm{mgChl} a)^{-1} \mathrm{~h}$ ${ }^{1}\left(\mu \mathrm{Em}^{-2} \mathrm{~s}^{-1}\right)(0.02$ to 0.16$)$ in Bedford Basin and 0.01 $\mathrm{mgC}(\mathrm{mgChla}))^{\prime} \mathrm{h}^{1}\left(\mu \mathrm{Em}^{-2} \mathrm{~s}^{-1}\right)(0.003$ to 0.015$)$ in Scott Inlet.

Table III shows the significant correlations $(p<0.05)$ between environmental factors and P-I curves parameters. $\alpha^{\mathrm{B}}$ was negatively correlated to $\mathrm{k}$ and nitrate and $\mathrm{P}^{\mathrm{B}}$ max positively with incident light $\left(\mathrm{I}_{\mathrm{o}}\right)$ and negatively with $\mathrm{k}$. Light, probably, was a limiting factor in some of the time of the annual cycle. 

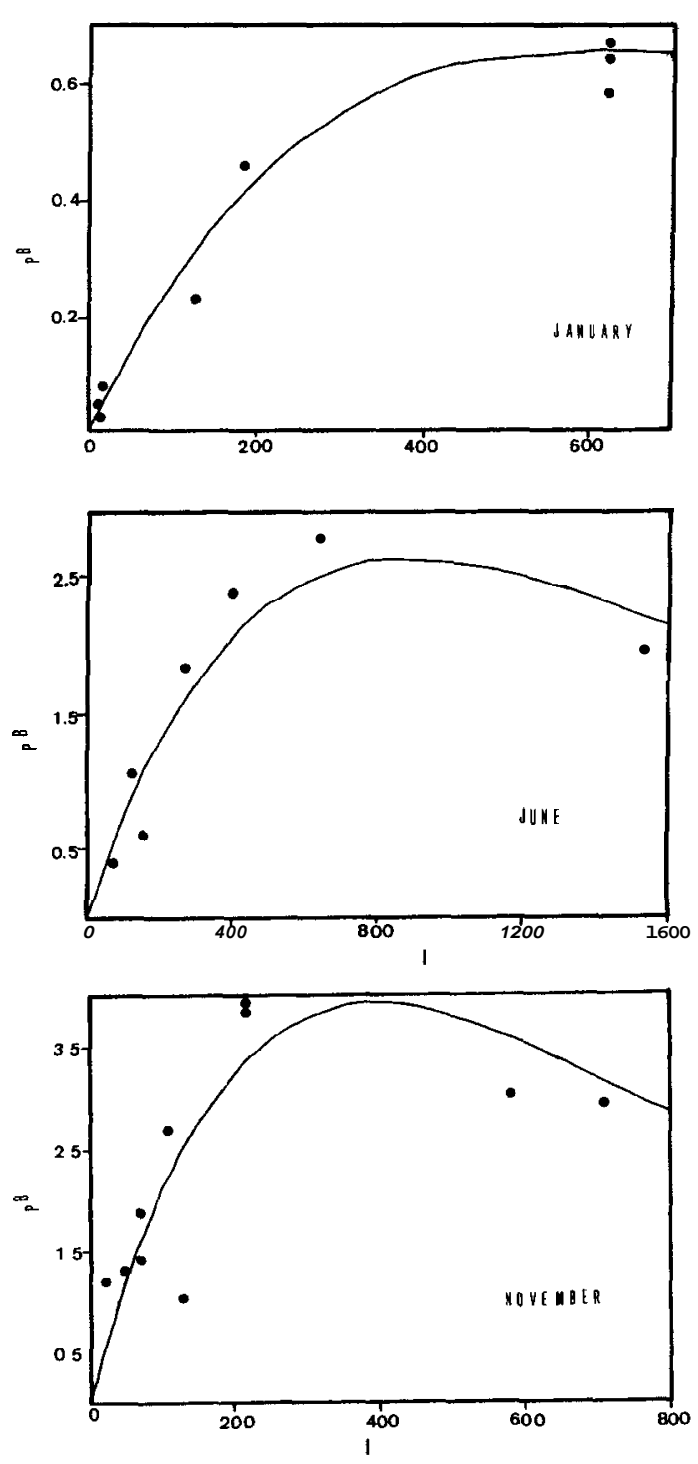

FIGURE 6. Examples of Photosynthesis-Irradiance (P-I) curves in estuarine phytoplankton assemblages from January, June and November.

FIGURA 6. Ejemplos de las curvas Fotosíntesis-Irradiancia obtenidas con muestras de fitoplancton de estuario de Enero, Junio y Noviembre.

The effect of nutrient availability on $\alpha^{\mathrm{B}} \mathrm{y} \mathrm{P}^{\mathrm{B}}$ max is not well documented. COTE and PLATT (1983) suggested that if nutrient stress decreases the size of photosynthetic units (PSU) (FALKOWSKI, 1981; PERRY et al., 1980), $\alpha^{B}$ would be expected to increase with nutrient limitation. Nitrogen concentration in the Pas estuary was high during the main part of year (Fig. 3B) the same as DIN:SRP ratios (Fig. 3C); only in summer (June-September) the nitrate concentration was low (5 $\mu \mathrm{M})$ and DIN:SRP ratios less than 10:1. We think that had no limitation for nitrogen. PEREZ and CANTERAS (1991),
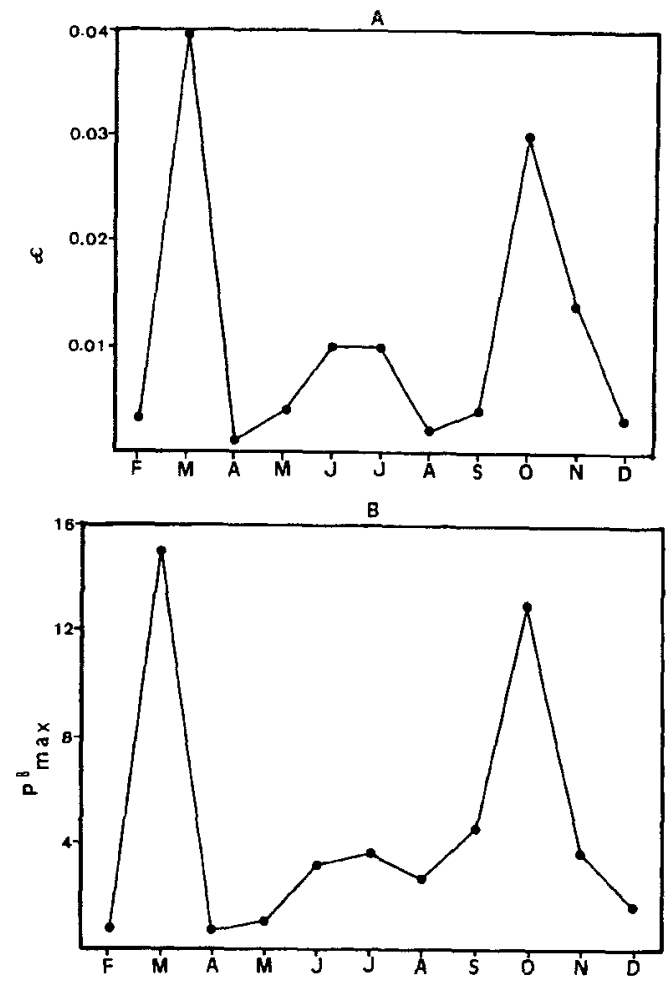

FIGURE 7. Temporal variations of $\mathrm{a}^{\mathrm{s}}$ (a) (mgC(mgChla) ${ }^{\prime} \mathrm{h}\left(\mu \mathrm{Em}^{2} \mathrm{~s}^{-1}\right)$ and $\mathrm{P}^{\mathrm{B}} \max$ (b) (mgC(mgChla)'h-').

FIGURA 7. Variaciones temporales de $\alpha^{\mathrm{B}}$ (a) $\left(\mathrm{mgC}(\mathrm{mgChl} a)^{\prime} \mathrm{h}\right.$ ' $\left(\mu \mathrm{Em}^{2} \mathrm{~s}^{-1}\right)$ and $(\mathrm{b}$ ) $P^{B} \max \left(\mathrm{mgC}(\mathrm{mgChl} a)^{-1} \mathrm{~h}\right)$.

through bioassay experiments and the study of DIN:SRP relations, verified the phosphate limitation in the Pas estuary. We believe it is difficult to think that $\alpha^{B}$ is negatively correlated to nitrate concentrations through the stress created in the size of PSU, by phosphoruos limitation. CULLEN (1991), suggests that in the bibliography there are different results, obtaining high photosynthetic parameters when the nutrients are low and reciprocally. He thinks it is necessary to leave these conclusions.

The results obtained, in this paper, suggest $\alpha^{\mathrm{B}}$ and $\mathrm{P}^{\mathrm{B}}$ max are related to the specific composition and cell size of phytoplankton community. The highest values of $\alpha^{\mathrm{B}}$ and $\mathrm{P}$ max belong to samples in which community was dominated by

TABLE III. Significant correlations $(\mathrm{P}<\mathrm{O} .05)$ between environmental factors and P-I curve parameters.

TABLA III. Correlaciones significativas $(P<0.05)$ entre factores ambientales y los parámetros de las curvas $\mathrm{P}-\mathrm{l}$.

\begin{tabular}{llll}
\hline & 10 & $\mathbf{k}$ & Nitrate \\
\hline$\alpha^{\mathrm{B}}$ & $\mathbf{n . s .}$ & -0.49 & -0.53 \\
\hline $\mathrm{P}^{\mathrm{R}} \max$ & 0.60 & $\mathbf{0 . 5 0}$ & n.s. \\
\hline
\end{tabular}


opportunistic and typical estuarine species (Cryptomonas sp., Skeletonema costaturn, Thalassiosira sp., Gymnodinium minus). These species are small-sized, have an elevated growth rate and are able to survive in superficial waters and wellilluminated areas. The lowest values correspond to communities dominated by fresh water species (Rhoicosphenia curvata, Asterionella formosa). Intermediate values are related to marine communities (Rhizosolenia stolterforthii, Bacteriastrum hyalinum, $B$ delicatulum). This paper shows that

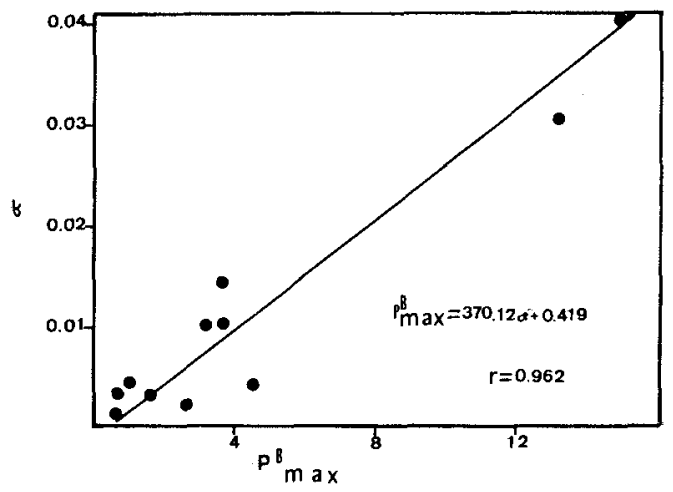

FIGURE 8. Plots of $\alpha^{\mathrm{B}}$ versus $\mathrm{P}^{\mathrm{B}} \max$. Data were analyzed by least-squares linear regresion. Regression equation and correlation coefficient are presented. FIGURA 8. Regresión entre $\alpha^{\mathrm{B}}$ y $\mathrm{P}^{\mathrm{B}} \max$. Se presenta la ecuacion de regresión y el coeficiente de correlación.

$\mathrm{ci}^{\mathrm{B}}$ and $\mathrm{P}^{\mathrm{B}}{ }_{\max }$ increase when dominant species are small-sized and are related to the marine and estuarine waters.

The initial slope $\left(\mathrm{a}^{\mathrm{B}}\right)$ has been plotted versus $\mathrm{P}^{\mathrm{B}} \max$ (Fig. 8). There is a strong dependence between both parameters $(\mathrm{r}=$ $0.962, \mathrm{P}<0.001)$. A correlation between $\boldsymbol{\alpha}^{\mathrm{B}}$ and $\mathrm{P}^{\mathrm{B}} \max$ has been observed before for laboratory cultures and natural assemblages of phytoplankton (MAcCAULL and PLATT 1977; HARDING et al., 1982). The dependence between ci $^{\mathrm{B}}$ and $\mathrm{P}^{\mathrm{B}}{ }_{\max }$ indicates that these processes are coupled dynamically within the cell, so that the action of one provides the energy to drive the other.

\section{REFERENCES}

COTE, B. \& PLATT, T. 1983. Day-to-day variations in the spring-summer photosynthetic parameters of coastal marine phytoplankton. Limnol. Oceanogr. 28(2):320-344.

CULLEN, J.J. 1991. Nutrient Limitation and Marine Photosynthesis: A good paradigm is Hard to Find. In : Primary Productivity and biogeochemical cycles in the sea. Brookhaven Symposia in Biology no. 37: 69-88. New York.

FALKOWSKI, P.G. 1981. Light-shade adaptation and assimilation numbers. J Plankton Res. 3:203-216.
HARDING, L.W.; PREZELIN, Jr. B.B.; SWEENEY, B.M. \& COX, J.L. 1982. Diel Oscillations of the Photosynthesis Irradiance (P-I) Relationship in Natural Assemblages of Phytoplankton. Mar. Biol. 67, 167-178.

HARRISON, W.G. \& PLATT, T. 1980. Variations in the assimilation number of coastal marine phytoplankton: Effects of environmental covariates. J.Plankton Res. 2: 249-260.

HARRISON W.G., PLATT, T. \& LEWIS, M.R. 1985. The utility of light saturation models for estimating Marine Primary Productivity in the Field: A comparison with conventional "simulate" in situ methods. Can. J. Fish. Aquat. Sci. 42: 864-872.

MAcCAULL, W. A. \& PLATT, T. 1977. Diel variations in the photosynthetic parameters of coastal marine phytoplankton. Limnol. Oceanogr. 22:723731.

PEREZ, L. 1987. Distribucción y dinámica del fitoplancton en el estuario del río Pas (Cantabria). Tesis doctoral. Univ. Granada. 292 pp.

PEREZ, L. \& J.C. CANTERAS. 1990. Caracteristicas físicas, quimicas y biológicas del estuario del rio Pas (Cantabria). Scienctia Gerundensis. 16/2:79-98.

PEREZ, L. \& CANTERAS, J.C. 1991. Inlfluencia de la temperatura y de los nutrientes en la producción primaria del estuario del río Pas (Cantabria, Spain). Submitted to Scientia Marina.

PERRY, M. J.; TALBOT, M.C. \& ALBERTE, R.S. 1980. Photoadaptation in marine phytoplankton: Response of the photosynthetic unit. Mar. Biol. 62: 91-101.

PLATT, T. \& JASSBY, A. 1976. The relationship between photosynthesis and light for natural assemblages of coastal marine phytoplankton. J. Phycol. 12:421-430.

PLATT, T.; GALLEGOS, C.L. \& HARRISON, W.G. 1980. Photoinhibition of photosynthesis in natural assemblages of marine phytoplankton. J. Mar. Res. 38(4): 687-701.

STEEMAN-NIELSEN, E. 1952. The use of radioactive carbon (14C) for measuring organic production in the sea. $\mathbf{J}$. Cons. Int. Exp. Mer. 18:313-323.

STRICKLAND, J.D.H. \& PARSONS, T.R. 1972. A practical handbook of seawater analysis. Fisheries Research Board Bulletin, Canada $167 \mathrm{pp}$.

UTERMOHL, H. 1958. Zur VerYollkommnung der quantitativen PhytoplanktonMethodik. Mitt. Int. Verein. Theor. Angew. Limnol. 9,1-38.

VOLLENWEIDER, R.A. 1969. Calculations of photosynthesis depth curves and some implications regarding day rate estimates in primary production measurements. In: GOLDMAN, C.R. (ed.): Primary productivity in aquatic environments: 425457. Suppl. Univ. California Press, Berkeley. 